\title{
Current History and National Affairs of Nepal
}

\author{
Prof.Dr. Meena Ojha*
}

\begin{abstract}
One can find chains of people's struggle for freedom nationality, national, unity, integrity and democracy for centuries past when studies and researches carried out into the History of Nepal. People's participation in such struggles can't be exaggerated as the people themselves are the creators of the history. Because of apathy, insincere activities, inability, unclearity in vision and objective of political leadership, economic development and task of building new Nepal always remained limited only in speech and futile ambition.
\end{abstract}

Keywords: People's movement, Political parties and Federal democratic republic.

The historical People's Revolution of 1950 for freedom, sovereignty and democracy had become successful due to long time struggle, sacrifice and dedications of thousand people, patriots and participation of political parties. February 18, 1950 was the historical day when Rana Regime had ended. Since then, February 18 began to be celebrated as the Democracy day (Pradhan, 2047 : 13-17 ). This is supposed to be politically successful on the one hand and is also blamed as the "Day of Betrayal" on the other. Be that as it may, the 1950 revolution has occupied an important place as a long -affecting event in the history of Nepal.

After the end of 104 years long family rule of Ranas in 1950, Interim Constitution was introduced by King Tribhuvan through royal announcement promising before the nation that the nation would take a path towards republican system through elections for constituents Assembly. This event proved to be a milestone for the effort to lead Nepal towards development and prosperity.

Left behind groping about in the darkness and remaining out of the sight of the world, Nepal could take steps towards the external contact and establish relationship with different countries of the world. As a result, waves of modern development began to take place in Nepal. Efforts for the development of political culture based on democratic principal, norms and values were made time and again, instability and confusion got encouraged due to different problems and chaotic situation of the country. Political fighting and interparty

* Dr. Ojha is a Professor of the Department of History and Buddhist Studies, T.U., Patan Multiple Campus, Patan Dhoka. 
fighting overshadowed the national interest and development works. Distance among political parties due to fighting for power went escalating (Joshi and Rose, 1966 : 96).

Conflicts and clashes among political leaders kept on intensely increasing. Gap between the king and political parties also went on deepening. The Constitution on Nepal 1958 granted more power to the king making him the supreme of the nation. The long awaited election for Constituents Assembly proved to be pure illusion. It was changed into parliamentary election. First ever General Election for multiparty parliamentary system was held. Nepali Congress secured two-third majority in the parliament.

First elected government was formed under the leadership of Nepali Congress leader B.P Koirala. Policy, programs and plans were made public by Nepali Congress government. But the opposition political parties did not pay attention to implement them, rather they began to make protest programs against the government with intention of pulling down the Congress government. Several problems and disturbance were created against government of Nepali Congress.

The government was put in difficulties in a way that it could not work well. No efforts were made for mutual cooperation, consensus and understanding among political parties. As a result, political instability and confusion increased in the country. At the same time ambitious activities of King Mahendra begain to surface. He made a plan for national wide visit. He started his visiting campaign and delivering speeches to masses of people. The purpose of his national wide visit was to learn the people's opinion about the political situations and multiparty system. His speeches contained something important and long affecting intention to be seriously analyzed by the political parties including the Nepali congress. But, neither the B.P led Congress Government nor other opposition parties tried to find out or could see something black floating in the milk.

Rather they engaged in fighting and quarrel among themselves not heeding what King Mahendra was doing and planning. Political culture and conduct was totally renounced. As a result of the weakness and of the ruling Nepali Congress and jealousy of other political parties with the ruling congress, King Mahendra balantanly took over the power , imposed ban on political parties and introduced Autocratic Panchayat System under his own leadership. Since then, monarchy became supreme power of the nation. Political leaders were arrested, imprisoned for long time. Those leaders who could flee away had to live in exile or go underground.

During the period from 2017 to 2035, students played the roles of opposition party. During the whole 30years period of Panchayat autocratic system, most of the anti-government or 
anti-Panchayat movement were initiated and directly led by students. As a result of the student agitation of 2035-36 B.S referendum was announced by the then King Birendra. The effect and inspiration of 2037 BS referendum made the Joint People's Movement of 1990 successful to overthrow the 30 years long Panchayat System. Then multiparty parliamentary system was established in the country in 1990. The Constitution of the Kingdom of Nepal1990 was a document of contract (agreement) between political parties and king Birendra. The role of government, opposition and other political parties could not be strong and mature as should have been in multiparty parliamentary of governance. Disappointment and frustration came up to the people. Aspiration and expectations of the people were felt betrayed. (Shah, 1992 : 39)

During the 14 years period of parliamentary system from 1991 to 2004, neither any House Representatives formed by elections nor the government could complete their term of office. Total 13 governments were formed one after another during the 14years period due to pulldown and push up games stages by the parliamentary political parties for the power. Even in party fighting and quarrel used to reach the climax. When one leader of a party would form government under his leadership, the other leaders of the same party would form government under his leadership, the other leader of the same party would hatch conspiracy and form gang to help topple down the prime minister or the government of their own party. Different parties got spitted under different leaders. Different parties would call 'Nepal Closer' (Nepal Bandha) to put pressure to the government for meeting their group interest. Sometimes, political leaders of parliament formed 'Jumbo' council of ministers for staying in power for long time. Internal conflicts in political parties increased. Parliamentary meetings were disturbed or postponed and street agitations were intensified for months. corruptions got encouraged and became rampant in every sector of nation. National Treasury was emptied for buying MPs for endorsing confidence or no-confidence motion led Nepal towards instability and confusion.

Anarchy spread throughout the country. Realizing such situation a team of parliament members presented 40-point demands to then prime minister Sher Bahadur Deuba for finding out solutions. The government led by Deuba did not care for demands nor thought necessary to address the problems mentioned in the 40-points demands. As a result, the nation had to go through 10-years long armed 'People's war' led by CPN (maoist) During the 10years period of armed conflict different governments restored to suppress or crush the armed struggle but in vain. They imposed emergency, accused the Maoist terrorists, and announced prices of the heads of some Maoist leaders saying that whoever would help security forces to arrest Maoist leaders or cut off their heads and hand over to the security 
forces or to the government would be awarded cash prizes. The situation of the country went on worsening (Hoftum, Raeper \& Whepton, 1999 : 3-9).

The terrific event of Palace Massacre put question marks on monarchy. Parliamentary activities became very weak and could not do anything for the nation. Polarization increased in political parties. Deuba led government recommended dissolution of the parliament within the stipulated. So the then King Gyanendra took over all the executive power in himself showing the reason that Prime Minister Deuba was proved incompetent to hold the elections as well as lead the government affairs. Then the parliamentary parties started street agitation. They continued agitation against retrogressive move King Gyanendra demanding the restoration of dissolved parliment. Restoration of parliment was the main agenda of the parliamentary political parties. On the other side, Maoist 'People's War' was strongly escalating thorough out the nation. Nepal had to bear the burnt of the War, loss of people and billians worth property. According to the report of Nepal Human Right Commission. The 10years long 'People War' took the lives of more than 13 thousands 2 hundres 70 people, more than 3hundreds 47childrens lost their lives. More than 3.2 millions people lost their shelters. More than 36 millions Rupees was spent on arms and ammunitions. More than 3 thousands events of fighting and scuffles took place. Where about of more than 15thousands people remained unknown or disappeared.

Such sorrowful conditions of the people and people and nation created a situation for the political parties to jointly find a political solution. Intellectuals, civil society, professional organizations, social workers including the general public's began to raise voices for the end of the instable politics and restoration of peace and security in the country. Friendly countries and international community also was of the view that the political parties and CPN (Maoist) should work together and find out proper political solution of the problems to bring the country in normal situation through through democratic men's, norms and values paired with human rights (Baral, 2006 : 99).

The role and the supports given by neighboring countries and international communities to the Nepalese people for the success of 1950 Revolution and Joint People's Movement of 2007 cannot be exaggerated . Comments directed towards this question from time to time has also made people aware and dutiful to the nation. In the same course, the 12-point understanding (consensus) commonly signed by the CPN (Maoist) and 7-party Alliance declared Joint People's Movement the Royal take over by King Gyanendra. The dissolved parliament was restored by king Gyanendra being compelled by the 19-days historic joint Movement. Compressive peace agreement was signed between the government of 7-party 
Alliance and CPN (Maoist). Then the 10-yers long armed 'People's War ' was categorically ended. Interim constitution was formulated and promulgated.

Lack of adequate homework's, Far-sightedness and clear vision, inability to focus attention on overall situation of the country, negligence of intellectual discussions and interactions etc. were the weakness of the then government and political parties. On the other they had to take help of general public's. At the time when the aspirations wants and expectations of the people were mounting, they had to start agitation as compulsion. Terrific events took place at different place of the country. Since the political leaders did not become sensitive nor did they show readiness to solve problems, Madhesi movement emerged in a violent form. Dozens of Nepalese got martyrdom, billians worth physical property were destroyed. The 23-day movement launched by the Madhesi people became successful to change even the system of state. Kathmandu, the central government cannot neglect any race/cast, community, language, region, class, religion, culture etc (Ralper \& Hoftum, 1992 : 3). The Madhes Movement did not only fulfill its demands but also create a compulsion for the central government to pay attention to every sector, region and look after them.

Madhesi people and political parties launched their movement demanding for federal system of state and representation to the power/government on the proportional basis of the population. In that agitation, evil and immoral efforts also were made to provoke sectarian and communial riots between Madhesi and Pahadi (between Teraian and Hilly people) and among different Madhesi communities (Adhikari, 2014 : 2). But the people did not lose discretion or judgement. The movement could not escalate to extereme. It was easily appeased. The political parties and interim government were solely responsible for the emergence of violent movement of Madhesi people. The voices of the Madhesi people were not given in interim Constitution even before its enforcement also put a question mark on the competency or ability of the constituent Assembly to start procedure as per Article 38 (2) to decide this issue on the basis of majority votes.

Nepalese people voted for changes, peace, security and governance by law. Giving first priority to the formulation of new Constitution of New Nepal, restructure of state in an inclusive way, protection of the interest of minority population, end of discrimination, guarantee for the right and interests of all citizen and make New constitution of New Nepal agreeable to all communities and political parties were the mandates of the Constituents Assembly. It was also necessary. To go to track of doing everything on the basis of simple majority breaking the people's mandate to formulate and promulgate New Constitution through consensus, it might be immaturity of the political parties. The political parties could not reach consensus for the adjustment of Maoist fighters including power sharing. They 
could not make a clear vision for the leading towards new changed and prosperous Nepal (Pislay, 1956 : 202). Most of the political parties seemed to have agreed to make Federal Constitution, but they could not show clarity how or what the structure of federal system be. they should also could not make consensus and understanding on the issue of federal structure and federal constitution.

The uniqueness of the change in Nepal could be felt from the fact that one third of 601-seats constituent Assembly were occupied by female members. This was the highest number in the South Assian region. According to the data provided by Inter Legislative Union, Nepal secured 14th place in this matter. The policies, plans, programms and target of political parites could be found clear. Instead, they remained busy in blaming and denigrating ane another making the people feel disappointed. They always gave priority to organize general strikes, closers(bandas), street demonstrations agitations etc. gathering the general people doing out one or the other hopes. They could not be dedicated to the democratic culture nor tried to develop it due to which negative political games took place several times because of the lack of nationally revered as well as internationaly recognizable political leader, Nepal's political situation remained confusing and disappointing. Political parties did not pay attention towards institutional development of political and democracy nor did they try to improve the character of political leaders. If the all the political parties, civil society, all classes and communities marched ahead dedicating themselves to the national interest spreading patriotic sentiment, the country could get justice.

It is to do politics for the interest of the nation and people through intellectual discussions, but not for the power and wealth. Civil society, market economy and government should go together. They should give first priority to good governance. The necessity of the history is to build a developed and prosperous Nepal through mutual contribution, dedication and sacrifice. The political leaders should not give oral assurance and dole out hopes to the people, rather they should be more pragmatic and dedicated themselves to materialize the people's mandate and renounce discriminations. There are many problems in the country . The people have become more aware. In the era of 21st Century the politics and political culture of Nepal has become democratic. Youth, students, general public's , civil society, women all classes and communities are found to have given first priority to political parties and leaders should not be poles apart. That the necessity of Federal Democratic Republic of Nepal is the system of life and living of all Nepalese people should be realized by all the political parties and leaders concerned. 


\section{References}

Adhikari , Aditya, (2014), The Bullet and the ballot box, London, Aleph book company. Baral, Lok Raj, (2006), Oppositional Politics in Nepal, New Delhi: Amol Publication.

Hoftum, Martine, (1999), William Raeper \& Johan Whepton, People, Politics and Ideology: Democracy and social change in Nepal, Kathmandu: Mandala books.

Joshi, Bhubanlal \& Rose, Leo E, (1996), Democratic Innovations in Nepal, Barkley: Books Points. Ojha, Meena, (2012), The Student Politics \& Democracy in Nepal, New Delhi: Nirala Publication Pislay, Avos J., (1956), Constitution of the Nations, London: The hague.

Pradhan, Bhubhanlal, (2074), Nepal ko Jana Kranti-2007, Rumu Prakashan.

Raeper. William \& Hoftune, Martine, (1992), Spring Awakening, New Delhi: Viking. Shah, Rishikesh, (1992), Politics in Nepal 1980-1991, India: Monahar publishers and distributors. 